Volume 21 (2021) Issue 2

DOI: $10.2478 /$ foli-2021-0016 | 57-75

ISSN (print): 1730-4237 | ISSN (online): 1898-0198

www.wnus.edu.pl/fos

open 2 Access

\title{
SUSTAINING SOUTH AFRICAN SMALL AND MEDIUM-SIZED ENTERPRISES \\ THROUGH MONETARY ACCESS AND LITERACY IN THE COVID-19 ERA
}

Thabiso Sthembiso Msomi, Masters Student (MAcc)

Department of Management Accounting

Faculty of Accounting and Informatics

Durban University of Technology, South Africa

e-mail: mndayithabiso@gmail.com

ORCID: 0000-0003-3941-6815

Odunayo Magret Olarewaju, Ph.D., Senior Lecturer

Department of Management Accounting

Faculty of Accounting and Informatics

Durban University of Technology, South Africa

e-mail: odunayoo@dut.ac.za

ORCID: 0000-0002-4366-040X

Xolani Ngcobo, Masters Student (MAcc)

Department of Management Accounting

Faculty of Accounting and Informatics

Durban University of Technology, South Africa

e-mail:nyuswaxm@gmail.com

ORCID: 0000-0003-2761-1103

Received 21 June 2021, Accepted 17 October 2021

\begin{abstract}
Research background: Monetary access and literacy are significant factors of concern confronting the survival and sustainability of small and medium-sized enterprises.

Purpose: This led to this paper seeking to understand the impact monetary access and monetary literacy have on the sustainability of SMEs in the COVID-19 era.

Research methodology: The method was employed by this study is a quantitative research method, which is supported by a positivism research paradigm. Data was collected using a questionnaire completed by 310 sampled participants. Using the Statistical Package for Social Sciences to analyse data, descriptive, the Pearson correlation and regression analyses were used to estimate the model.
\end{abstract}

Results: The Pearson correlation indicated a positive and significant correlation between monetary access and monetary literacy to the sustainability of small and medium-sized enterprises $(r=0.564)$. The result 
indicated that some small and medium-sized enterprises do possess basic monetary skills while some do not. A significant number of small and medium-sized enterprises do not understand basic monetary terms, which justifies the lack of monetary literacy.

Novelty: The study recommends that government agencies that assist with business registration should include a monetary training course as part of registration formalities. Further to that, the study recommended that government, banks and other business support institutions should simplify support programmes for the prosperity of small and medium-sized enterprises during and post COVID-19 pandemic.

Keywords: Monetary Access, monetary Literary, small and medium-sized enterprises, sustainability

JEL classification: L21, L26

\section{Introduction}

Small and medium-sized enterprises (SMEs) are recognised as pillars of the global economy as they stimulate economic prosperity, reduce hunger and contribute to the production of employment (Bushe, 2019). For this reason, policymakers all over the world are paying keen attention to the growth of this field. In the South African economy context, SMEs are important contributors to economic development and growth as they make an important contribution to the national gross domestic product (GDP) and help in the reduction of unemployment. Furthermore, South Africa has economic problems as a result of the COVID-19 epidemic, which has disrupted the global economy and social settings. Many South African SMEs are ill-equipped to deal with the economic stalemate (Yuesti, Rustriarini, Suryandari, 2020). The poor level of monetary awareness is partly to blame for the unforeseen circumstances and people's lack of preparedness. According to research, monetary illiterate people are more likely to be exploited by conventional and informal intermediaries, resulting in greater financing expenses (Choi, Laibson, Madrian, 2010; Msomi, Olarewaju 2021). In addition, a lack of adequate monetary literacy is linked to the incapacity to analyze and make more informed decisions about business funds. However, evidence has been found that SMEs are invariably confronted with a slew of challenges including a lack of entrepreneurship education, a scarcity of business awareness (Ye, Kulathunga, 2019) and a lack of easy access to capital, particularly bank resources. According to the literature, about $75 \%$ of SMEs in South Africa collapse after two years of service as a consequence of these barriers. ${ }^{1}$

\footnotetext{
1 https://endeavor.co.za/2019/10/70-of-smes-fail-within-the-first-two-years-can-fintech-be-the-game-changer.
} 
Moreover, monetary illiteracy along with monetary access have been mentioned as a contributor to the slow development of most small enterprises in South Africa (Owusu, Ismail, Osman, Kuan, 2019; Rambe, Mosweunyane, 2017). More often enterprises are poorly managed and financed, leading to the overall rate of failure of SMEs (Kitomo, Likwachala, Swai 2021). It is difficult to overstate the importance of monetary literacy across individuals, families, as well as the South African economy as a whole (Van Deventer, De Klerk, 2017). The success and productivity of any economic participant depends on the value of literacy they acquire. In a business environment monetary knowledge and background is an important sustainability tool as it assists in better monetary decision-making, investing and capital appraisal decisions.

Despite attempts by banking institutions, the private sector, as well as the government to boost monetary access among SMEs in the country (Muo, Oladimeji, Okunbadejo, 2020), further efforts need to be made to guarantee that finance is more easily obtainable. According to Leboea (2017), the lack of funding in South Africa impedes SMEs' growth and survival, culminating in most enterprise life spans being ended prematurely. The value of monetary literacy cannot be understated to sustainable business environment and the background failure of SMEs' is modified by the lack of monetary knowledge by most business owners (Manzoor, Wei, Sahito, 2021). As much as the South African government has made a number of attempts to assist SMEs in business growth through agencies such as SEDA, a number of SMEs still fail. Monetary literacy imposes a huge impact on the business environment and has been a factor that has been overstated but not emphasised.

There is an immense high failure rate in the SMEs business sector particularly in South Africa (Bushe, 2019). This is modified by a number of factors such as lack of capital, poor management strategies, monetary management and business knowledge. The majority of developing countries have low literacy rates, with only $32 \%$ of adults in sub-Saharan Africa being monetarily literate (Lyons, Kass-Hanna, Liu, Greenlee, Zeng, 2020). As a result, founders are seen making and adopting reckless monetary choices, culminating in the premature collapse of a variety of small businesses. SME owners must also be encouraged and must have ready access to the tools needed for their businesses to expand and survive. Monetary literacy seeks mainly to ensure that people can navigate a complex spectrum of monetary goods and services (Grohmann, 2018). It is also clearly true that managers with a good position in the conduct of their business have a favourable effect on their viability because they can take good monetary decisions (Mabula, 2016).

This study is highly important and special since the study results could enable small business owners and managers to appreciate the need for monetary education to increase their 
level of monetary literacy. The results also aim to increase the understanding of SME owners or managers of how finance providers' function. This should assist them to be more able to obtain access to bank funding. Secondly, South Africa's government sees SMEs as critical to the country's economic development. As a result of the study's results, the government will be able to recognise the disparity in monetary literacy and monetary access problems faced by SMEs and develop strategies to have tailor-made solutions. The findings would also help the government develop policies intended to boost monetary literacy amongst entrepreneurs and, as a consequence, enhance their capacity to access capital. The study's results will also help academic institutions better understand the significance and involvement of SMEs in the country. As a result, these institutions will devise strategies to integrate monetary education into the learning environment while still ensuring that all pupils, rather than only a selected few (business and management students only), learn from it. Fourth, the results of the study will aid monetary companies in developing approaches to help businesses in improving their monetary literacy standards by the implementation of easily available and convenient educational programmes. The results would also help monetary institutions build realistic and long-term funding solutions. As a result, monetary institutions will be mindful of the ability of the SME sector and will evolve appropriate strategies to address the needs of SMEs in the municipalities and the country as a whole. Finally, the report aims to fill a void in the literature on monetary literacy and monetary access, as well as a link to current scholarly information that can be used as a foundation for future research.

\section{Literature review}

Several prior studies have discovered a clear and optimistic connection between monetary literacy and monetary access. Furthermore, observational evidence shows that monetary restrictiveness and SME growth are negatively associated with monetary access. According to Usama and Yusoff (2018), better monetary access for SMEs will be achieved if there is a high degree of monetary literacy. As a result, SME owners and administrators with a higher degree of monetary literacy have a greater chance of obtaining financing. According to Chaudhuri, Sasidharan and Raj (2020), monetary access is undoubtedly the greatest impediment to SMEs' progress. The prospect of SMEs thriving in developed economies has remained low, exacerbated by a lack of monetary skills (Ndiaye, Razak, Nagayev, Ng, 2018). Monetary literacy is considered to be an indicator of investing habits such as stock market engagement (Garg \& Singh, 2018), low-risk investment portfolio collection, enhanced diversification and increased incidence 
of stock trading. Poor levels of monetary literacy have been linked to bad credit conduct, such as lending at ridiculous rates and mortgage recidivism (Barua, Koh, Mitchell, 2018). Monetary literacy, according to the Grohmann, Klühs and Menkhoff (2018), is a tool for improving service performance and quality. Improving the availability of monetary goods in order to increase monetary access would be ineffective unless it was followed by monetary literacy promotion, because customers would not appreciate these items if they did not realise their value (Kamanga, 2018). One of the major constraints to SMEs' long-term viability has been described as access to capital. Most SMEs are established with personal funds and family members, relatives and friends often contribute funds in exchange for a share in the business. It is more difficult for SMEs to obtain funding from banks, capital markets or other credit providers.

Previous studies of scholars like Ye and Kulathunga (2019) described monetary literacy as an important source of information for making monetary decisions. The impact of SMEs' monetary literacy on their long-term viability has received little attention. Monetary literacy was also found to be a predictor of monetary risk attitude and monetary access. The research used a questionnaire which was distributed to five chief financial officers (CFOs) of SMEs. The findings of this study revealed monetary risk attitude and access to finance as partial mediators of the relationship between monetary literacy and the sustainability of SMEs.

Sauh, Abdullah and Rahman (2021) outlined those businesses that needed sufficient financing to expand and that monetary access is the lifeblood of the industry. SMEs need funding to create new products, invest in science and expand their expertise. The willingness of a company to innovate, take risks and enter new or untapped markets is known as entrepreneurial orientation. Innovativeness, proactiveness, risk-taking, autonomy and competitive aggressiveness are all part of it. Pearson tests are used to test entrepreneurship qualities such as inventiveness, competitive aggressiveness and risk taking. Each dimension of entrepreneurial orientation can be evaluated separately. This is in line with previous research which has shown that individual entrepreneurial characteristics have a direct impact on business success. A survey analysis method was used in this report. Data from 368 SMEs was collected and analysed using Structural Equation Modelling (SEM). The study found an insignificant impact of finance access to business performance. No significant impact of innovation was retrieved on business performance, however risk-taking was directly associated with SMEs business performance.

According to Maziriri and Chivandi (2020), following the release of the 2015 Sustainable Development Goals by the United Nations, which aim to reduce inequality in all aspects and dimensions by 2030 , reducing inequality is becoming a major challenge in this ever-changing 
market climate. This study investigated the effect of entrepreneurship training, monetary literacy along with credit accessibility to credit for entrepreneurial success. In developing markets like South Africa, there is a paucity of studies on the effect of entrepreneurial activity, monetary literacy and availability of credit on start-up growth and poverty alleviation. The research took a methodological approach. The test was performed in the Vhembe District of South Africa's Limpopo province. Data from rural SMEs was collected using a standardised questionnaire. Results revealed that entrepreneurialism, monetary literacy as well as the availability of credit opportunities have a favourable impact on SMEs' start-up growth and poverty reduction.

For this study we employed the pecking order theory along with the human capital theory. The pecking order theory (POT) was first proposed by Donaldson in 1961 and was resurrected in 1984 by Myers and Majluf who focused their assertion on knowledge asymmetries. According to this theory, a business's real worth, investments and prospects are only understood by its managers and owners, according to Méndez-Morales (2019). Moreover, the theory states that companies are monetarily limited as a result of knowledge asymmetries amongst owners or administrators and customers and thus revert to using a hierarchy to choose sources of financing (Camfield, da Silva Freitas, Correia, Serrasqueiro, 2018). Myers (1984) observed that companies had a tendency to use a "pecking order" in investment finance, with internal equity coming first, accompanied by debt and finally external equity. This means that when firms' ordinarily created funds run out, they issue debt, then debt securities that include debt and finally shares (Chipeta, McClelland, 2018). If a company does not need a lot of money, it can use internal profits to satisfy its desires and debt can be released until the internal assets are depleted. As a result, a successful company will accumulate retained earnings, eliminating the need for external financing (Matias, Serrasqueiro, 2017).

On the other side, the human capital theory was developed by Mincer (1958), Schultz (1961) and Becker (1961) in the mid-twentieth century. The concept behind the human capital theory is that individuals will develop skills that will make them more efficient (Fix, 2018). This theory contends education or training as value adding to worker productivity by imparting valuable information and skills, thus increasing potential earnings and lifetime earnings (Mariri, Chivandi, 2020). Based on the preceding discussion, the human capital theory suggests that the type of business initiated is influenced by the level of education, field of education, previous entrepreneurial experience, previous business experience and business skills. If the human capital theory is taken into account it can help to boost entrepreneurship growth, as well as entrepreneurial attitudes, efficiency and activities amongst the working population in South Africa. SMEs play a key role in the economic growth of South Africa but the performance 
of these entrepreneurial ventures mainly depends on entrepreneurial human capital (Amin, 2018; Mariri, Chivandi, 2020). This theory has created a lot of discussion because it emphasises the value of human capital in entrepreneurship (Amin, 2018). The human capital theory will enable SME managers and employees to be more involved in business, thereby improving their living standards.

\section{Methodology}

This study used a quantitative research method, which adopts a positivism research paradigm. A favourable research instrument for this study was a Likert scale questionnaire with five-point response options. To justify the sample size, this research used the Cochran formula. According to Hoaglin (2016), the Conhran formula suggests that a target population is unspecified or too large. A total of 700 SMEs based in Durban; KwaZulu-Natal were included as a target population. A total of 321 SMEs in this analysis were sampled. Enabling the researcher to use his judgement, a judgemental sampling technique was used. Out of the 321 administered questionnaires, only 310 were returned and six of the returned were discarded because of errors. In total, 304 questionnaires were coded and analysed. The analysis presented was analysed using the Statistical Package for Social Sciences (SPSS).

SMEs fall into the category of small businesses, which are defined by the number of employees, total gross assets and overall total turnover range. Since the enterprises had between 10 and 200 staff, small and medium-sized business owners or a suitable representative of the SME owner in their enterprise were selected. Structured questionnaires were designed to collect primary data from SME respondents operating in Durban in order to meet the study's goal. Emails were sent as part of the recruitment process after respondents' email addresses were gathered from their websites and the SEDA database online. Each potential participant in the Durban Chamber of Commerce and Industry’s (DCCI) database was screened.

\section{Empirical findings and discussion}

\subsection{Descriptive review of study participants' feedback on SMEs' sustainability predictors}

The overall response rate of participants indicated variation on monetary literacy and monetary access. Significantly there was a higher level of agreement with the statements on monetary literacy, whereas some statements had a higher level of disagreement. However, 
the results indicated that monetary literacy is the hindering factor to the SMEs as only 33.2\% of them had undertaken basic accounting skills training and significantly in total of disagreement 49.7\% had not undertaken the training. Proportionately the result indicated that they have basic knowledge of the business environment and bookkeeping. However, some statements loaded a significantly neutral response at above $20 \%$ even spreading across the responses. With the aid of responses on monetary literacy it can be noted that as much as some SMEs have monetary knowledge, some do not have the knowledge and do not understand some accounting terminologies. This justifies the significant neutral response pattern among the responses.

Table 1. Responses on the Analysis of the Survey Response

\begin{tabular}{|c|c|c|c|c|c|c|}
\hline $\mathrm{S} / \mathrm{N}$ & Statements & $\begin{array}{l}\text { Strongly } \\
\text { disagree }\end{array}$ & Disagree & Neutral & Agree & $\begin{array}{l}\text { Strongly } \\
\text { agree }\end{array}$ \\
\hline 1 & 2 & 3 & 4 & 5 & 6 & 7 \\
\hline 1.0 & \multicolumn{6}{|c|}{ Monetary Literacy for SMEs' Sustainability } \\
\hline \multirow{2}{*}{1.1} & \multirow{2}{*}{$\begin{array}{l}\text { I can analyse the financial performance } \\
\text { periodically }\end{array}$} & $\begin{array}{c}48 \\
(15.8 \%)\end{array}$ & $\begin{array}{c}65 \\
(21.4 \%)\end{array}$ & \multirow{2}{*}{$\begin{array}{c}74 \\
(24.3 \%)\end{array}$} & $\begin{array}{c}86 \\
(24.3 \%) \\
\end{array}$ & $\begin{array}{c}31 \\
(10.2 \%)\end{array}$ \\
\hline & & \multicolumn{2}{|c|}{37.2} & & \multicolumn{2}{|c|}{34.5} \\
\hline \multirow{2}{*}{1.2} & \multirow{2}{*}{ I prepare monthly income statements } & $\begin{array}{c}53 \\
(17.4 \%) \\
\end{array}$ & $\begin{array}{c}82 \\
(27.0 \%) \\
\end{array}$ & \multirow{2}{*}{$\begin{array}{c}56 \\
(18.4 \%)\end{array}$} & $\begin{array}{c}80 \\
(26.3 \%) \\
\end{array}$ & $\begin{array}{c}33 \\
(10.9 \%)\end{array}$ \\
\hline & & \multicolumn{2}{|c|}{44.4} & & \multicolumn{2}{|c|}{37.2} \\
\hline \multirow[t]{2}{*}{1.3} & \multirow{2}{*}{$\begin{array}{l}\text { I have undertaken basic accounting } \\
\text { training }\end{array}$} & $\begin{array}{c}71 \\
(23.4 \%)\end{array}$ & $\begin{array}{c}80 \\
(26.3 \%) \\
\end{array}$ & \multirow{2}{*}{$\begin{array}{c}52 \\
(17.1 \%)\end{array}$} & $\begin{array}{c}63 \\
(20.7 \%) \\
\end{array}$ & $\begin{array}{c}38 \\
(12.5 \%)\end{array}$ \\
\hline & & \multicolumn{2}{|c|}{49.7} & & \multicolumn{2}{|c|}{33.2} \\
\hline \multirow{2}{*}{1.4} & \multirow{2}{*}{$\begin{array}{l}\text { My business has bought formal insurance } \\
\text { for the business }\end{array}$} & $\begin{array}{c}57 \\
(18.8 \%) \\
\end{array}$ & $\begin{array}{c}68 \\
(22.4 \%) \\
\end{array}$ & \multirow{2}{*}{$\begin{array}{c}55 \\
(18.1 \%)\end{array}$} & $\begin{array}{c}73 \\
(24.0 \%)\end{array}$ & $\begin{array}{c}51 \\
(16.8 \%)\end{array}$ \\
\hline & & \multicolumn{2}{|c|}{41.2} & & \multicolumn{2}{|c|}{40.8} \\
\hline \multirow[t]{2}{*}{1.5} & \multirow[t]{2}{*}{ I can compute the cost of loan capital } & $\begin{array}{c}9 \\
(3.0 \%) \\
\end{array}$ & $\begin{array}{c}47 \\
(15.5 \%) \\
\end{array}$ & \multirow{2}{*}{$\begin{array}{c}93 \\
(30.6 \%)\end{array}$} & $\begin{array}{c}108 \\
(35.5 \%)\end{array}$ & $\begin{array}{c}47 \\
(15.5 \%) \\
\end{array}$ \\
\hline & & \multicolumn{2}{|c|}{18.5} & & \multicolumn{2}{|c|}{51} \\
\hline \multirow[t]{2}{*}{1.6} & \multirow{2}{*}{ I have a savings account } & 0 & $\begin{array}{c}20 \\
(6.6 \%) \\
\end{array}$ & \multirow{2}{*}{$\begin{array}{c}35 \\
(11.5 \%)\end{array}$} & $\begin{array}{c}61 \\
(20.1 \%) \\
\end{array}$ & $\begin{array}{c}188 \\
(61.8 \%)\end{array}$ \\
\hline & & \multicolumn{2}{|c|}{6.6} & & \multicolumn{2}{|c|}{81.9} \\
\hline \multirow{2}{*}{1.7} & \multirow{2}{*}{$\begin{array}{l}\text { I am aware of the required documents } \\
\text { to get a loan from a bank to fulfil our } \\
\text { financial needs }\end{array}$} & $\begin{array}{c}3 \\
(1.0 \%) \\
\end{array}$ & $\begin{array}{c}46 \\
(15.1 \%) \\
\end{array}$ & \multirow{2}{*}{$\begin{array}{c}73 \\
(24.0 \%)\end{array}$} & $\begin{array}{c}122 \\
(40.1 \%)\end{array}$ & $\begin{array}{c}60 \\
(19.7 \%) \\
\end{array}$ \\
\hline & & & & & & \\
\hline 1.8 & I am aware of the costs and benefits & $\begin{array}{c}6 \\
(2.0 \%) \\
\end{array}$ & $\begin{array}{c}49 \\
(16.1 \%) \\
\end{array}$ & $\begin{array}{c}78 \\
0\end{array}$ & $\begin{array}{c}118 \\
(38.8 \%) \\
\end{array}$ & $\begin{array}{c}53 \\
(17.4 \%) \\
\end{array}$ \\
\hline & & & & & & \\
\hline 1.9 & I can calculate the interest rates and loan & $\begin{array}{c}8 \\
(2.6 \%) \\
\end{array}$ & $\begin{array}{c}30 \\
(9.9 \%) \\
\end{array}$ & 73 & $\begin{array}{c}124 \\
(40.8 \%)\end{array}$ & $\begin{array}{c}69 \\
(22.7 \%) \\
\end{array}$ \\
\hline & payments correctly & & & & & \\
\hline 1.10 & I have the skills required to assess & $\begin{array}{c}1 \\
(0.3 \%) \\
\end{array}$ & $\begin{array}{c}40 \\
(13.2 \%) \\
\end{array}$ & $\begin{array}{c}94 \\
(3000)\end{array}$ & $\begin{array}{c}117 \\
(38.5 \%) \\
\end{array}$ & $\begin{array}{c}52 \\
(17.1 \%) \\
\end{array}$ \\
\hline & & & & & & \\
\hline
\end{tabular}




\begin{tabular}{|c|c|c|c|c|c|c|}
\hline 1 & 2 & 3 & 4 & 5 & 6 & 7 \\
\hline \multirow{2}{*}{1.11} & \multirow{2}{*}{$\begin{array}{l}\text { I have skills for minimising losses } \\
\text { by minimising bad debts }\end{array}$} & $\begin{array}{c}4 \\
(1.3 \%)\end{array}$ & $\begin{array}{c}33 \\
(10.9 \%)\end{array}$ & \multirow{2}{*}{$\begin{array}{c}81 \\
(26.6 \%)\end{array}$} & $\begin{array}{c}105 \\
(34.5 \%)\end{array}$ & $\begin{array}{c}81 \\
(26.6 \%)\end{array}$ \\
\hline & & \multicolumn{2}{|c|}{$12.2 \%$} & & \multicolumn{2}{|c|}{$61.1 \%$} \\
\hline \multirow[t]{2}{*}{1.12} & \multirow{2}{*}{ I have basic accounting knowledge } & $\begin{array}{c}6 \\
(2.0 \%)\end{array}$ & $\begin{array}{c}41 \\
(13.5 \%)\end{array}$ & \multirow{2}{*}{$\begin{array}{c}74 \\
(24.6 \%)\end{array}$} & $\begin{array}{c}120 \\
(39.5 \%)\end{array}$ & $\begin{array}{c}63 \\
(20.7 \%)\end{array}$ \\
\hline & & \multicolumn{2}{|c|}{$15.5 \%$} & & \multicolumn{2}{|c|}{$60.2 \%$} \\
\hline \multirow{2}{*}{1.13} & \multirow{2}{*}{$\begin{array}{l}\text { I am aware that decision-making } \\
\text { in management is an essential skill } \\
\text { required for businesses as it determines } \\
\text { the success of the business }\end{array}$} & $\begin{array}{c}3 \\
(1.0 \%)\end{array}$ & $\begin{array}{c}15 \\
(4.9 \%)\end{array}$ & \multirow{2}{*}{$\begin{array}{c}41 \\
(13.5 \%)\end{array}$} & $\begin{array}{c}124 \\
(40.8 \%)\end{array}$ & $\begin{array}{c}121 \\
(39.8 \%)\end{array}$ \\
\hline & & \multicolumn{2}{|c|}{$5.9 \%$} & & \multicolumn{2}{|c|}{$80.6 \%$} \\
\hline \multirow{2}{*}{1.14} & \multirow{2}{*}{$\begin{array}{l}\text { I am aware of competition and always } \\
\text { consider better ways to improve } \\
\text { the business }\end{array}$} & $\begin{array}{c}1 \\
(0.3 \%)\end{array}$ & $\begin{array}{c}20 \\
(6.6 \%)\end{array}$ & \multirow{2}{*}{$\begin{array}{c}48 \\
(15.8 \%)\end{array}$} & $\begin{array}{c}97 \\
(31.9 \%)\end{array}$ & $\begin{array}{c}138 \\
(45.4 \%)\end{array}$ \\
\hline & & \multicolumn{2}{|c|}{$6.9 \%$} & & \multicolumn{2}{|c|}{$82.3 \%$} \\
\hline 2.0 & \multicolumn{6}{|l|}{ Monetary Access for SMEs' Sustainability } \\
\hline \multirow{2}{*}{2.1} & \multirow{2}{*}{$\begin{array}{l}\text { The financial services offered } \\
\text { by the bank have led to an improvement } \\
\text { in the business }\end{array}$} & $\begin{array}{c}20 \\
(6.6 \%) \\
\end{array}$ & $\begin{array}{c}45 \\
(14.8 \%)\end{array}$ & \multirow{2}{*}{$\begin{array}{c}116 \\
(38.2 \%)\end{array}$} & $\begin{array}{c}90 \\
(29.6 \%)\end{array}$ & $\begin{array}{c}33 \\
(10.9 \%)\end{array}$ \\
\hline & & & & & & \\
\hline \multirow{2}{*}{2.2} & \multirow{2}{*}{$\begin{array}{l}\text { The financial services offered } \\
\text { by the bank have improved our access } \\
\text { to sophisticated technology }\end{array}$} & $\begin{array}{c}21 \\
(6.9 \%) \\
\end{array}$ & $\begin{array}{c}51 \\
(16.8 \%) \\
\end{array}$ & \multirow{2}{*}{$\begin{array}{c}94 \\
(30.9 \%)\end{array}$} & $\begin{array}{c}105 \\
(34.5 \%) \\
\end{array}$ & $\begin{array}{c}33 \\
(10.9 \%) \\
\end{array}$ \\
\hline & & & & & & \\
\hline \multirow{2}{*}{2.3} & \multirow{2}{*}{$\begin{array}{l}\text { The financial services offered by the bank } \\
\text { have enabled us to pay utility bills }\end{array}$} & $\begin{array}{c}20 \\
(6.6 \%)\end{array}$ & $\begin{array}{c}44 \\
(14.5 \%)\end{array}$ & \multirow{2}{*}{$\begin{array}{c}109 \\
(35.9 \%)\end{array}$} & $\begin{array}{c}99 \\
(32.6 \%)\end{array}$ & $\begin{array}{c}32 \\
(10.5 \%)\end{array}$ \\
\hline & & & & & & \\
\hline 2.4 & The savings product provided & $\begin{array}{c}11 \\
(3.6 \%)\end{array}$ & $\begin{array}{c}43 \\
(14.1 \%)\end{array}$ & 132 & $\begin{array}{c}104 \\
(34.2 \%)\end{array}$ & $\begin{array}{c}14 \\
(4.6 \%)\end{array}$ \\
\hline & & & & & & \\
\hline 2.5 & The savings product offered by the bank & $\begin{array}{c}5 \\
(1.6 \%)\end{array}$ & $\begin{array}{c}42 \\
(13.8 \%)\end{array}$ & 93 & $\begin{array}{c}134 \\
(44.1 \%)\end{array}$ & $\begin{array}{c}30 \\
(9.9 \%)\end{array}$ \\
\hline & & & & & & \\
\hline 26 & The loan product provided by the bank & $\begin{array}{c}13 \\
(4.3 \%)\end{array}$ & $\begin{array}{c}49 \\
(16.1 \%)\end{array}$ & 143 & $\begin{array}{c}82 \\
(27.0 \%)\end{array}$ & $\begin{array}{c}17 \\
(5.6 \%)\end{array}$ \\
\hline & & & & & & \\
\hline 2.7 & The terms and conditions on bank loans & $\begin{array}{c}8 \\
(2.6 \%)\end{array}$ & $\begin{array}{c}38 \\
(12.5 \%)\end{array}$ & $\begin{array}{c}150 \\
(49.3 \%)\end{array}$ & $\begin{array}{c}81 \\
(26.6 \%)\end{array}$ & $\begin{array}{c}27 \\
(8.9 \%)\end{array}$ \\
\hline & are favourable to me & & & & & \\
\hline 2.8 & The financial services provided & $\begin{array}{c}10 \\
(3.3 \%)\end{array}$ & $\begin{array}{c}29 \\
(9.5 \%)\end{array}$ & 122 & $\begin{array}{c}106 \\
(34.9 \%)\end{array}$ & $\begin{array}{c}37 \\
(12.2 \%)\end{array}$ \\
\hline & by the bank are safe for us & & & & & \\
\hline 2.9 & The account opening fees charged & $\begin{array}{c}6 \\
(2.0 \%)\end{array}$ & $\begin{array}{c}27 \\
(8.9 \%)\end{array}$ & 82 & $\begin{array}{c}114 \\
(37.5 \%)\end{array}$ & $\begin{array}{c}75 \\
(24.7 \%)\end{array}$ \\
\hline & & & & & & \\
\hline 2.10 & The cost of making a trip to the bank & $\begin{array}{c}11 \\
(3.6 \%)\end{array}$ & $\begin{array}{c}18 \\
(5.9 \%)\end{array}$ & 61 & $\begin{array}{c}126 \\
(41.4 \%)\end{array}$ & $\begin{array}{c}88 \\
(28.9 \%)\end{array}$ \\
\hline & is affordable & & & & & \\
\hline 2.11 & I lack access to information on getting & $\begin{array}{c}27 \\
(8.9 \%) \\
\end{array}$ & $\begin{array}{c}57 \\
(18.8 \%)\end{array}$ & 95 & $\begin{array}{c}83 \\
(27.3 \%) \\
\end{array}$ & $\begin{array}{c}42 \\
(13.8 \%) \\
\end{array}$ \\
\hline & & & & & & \\
\hline
\end{tabular}

Source: authors' calculation (2021). 
A similar response trend is observed with the monetary access statements, where responses are significantly spread on neutral responses, at more than $20 \%$ even spreading across responses. Some statements ranged from 40 to $49 \%$ of neutral responses. The overall responses presented on monetary access do indicate that SMEs have reasonable means to start their businesses, however they are not well informed of the support structures available like banks and government and they solely rely on themselves for monetary stability. The statements on monetary access are spread evenly among neutral and agreement level and lesser on disagreement level. Overall, the result highlighted that SMEs have a monetary literacy problem and no hindrance to monetary access. As much as they are informed of third-party like monetary institutions and government support financing, some have little understanding of it, indicated by the range of neutral responses. All in all, monetary literacy is a factor of hindrance to sustainability of the SME business sector.

\subsection{Descriptive statistics of study participants' answers as to where SMEs get resources}

Table 2 shows where businesses get their resources for the operation and sustainability of their businesses.

Table 2. Sources of Financing for SMEs

\begin{tabular}{|l|c|c|}
\hline \multicolumn{1}{|c|}{ Where SME owners get resources to sustain business } & Frequency & Percent \\
\hline Family and friends & 128 & 42.1 \\
\hline Commercial banks & 90 & 29.6 \\
\hline Venture capitalists & 34 & 11.2 \\
\hline Government agencies & 52 & 17.1 \\
\hline Total & 304 & 100.0 \\
\hline
\end{tabular}

Source: authors' calculation (2021).

The overall response rate of participants indicated where businesses get their resources from, and results were family and friends at $42.1 \%$, commercial banks at $29.6 \%$, venture capitalists at $11.2 \%$ and government agencies at $17.1 \%$. This result shows $42.1 \%$ of SMEs borrow money from family and friends.

\subsection{Correlation analysis: Pearson Correlation}

The outcome of the Pearson correlation coefficient conducted to establish the level of relationship between the constructs indicates a significant positive relationship between 
monetary access and monetary literacy for SMEs' sustainability. SMEs are also described by insufficient monetary and management competence. These flaws limit their ability to obtain funds from outside sources. The researchers discovered that monetary literacy has a favourable effect on monetary access, which is concordant with the finding by Kulathunga, Sharma and Weerathunga (2020) that monetary literacy was a significant determinant of monetary access. Furthermore, the results were in accordance with that of Udell (2020), who found that monetary literacy was significantly correlated to the knowledge of various monetary resources and the ability to recognise suitable sources of finance for an enterprise and Fernandez (2015), who discovered a momentous positive connection between the levels of monetary literacy along with the companies' operating performance. Bartolacci, Caputo and Soverchia (2020) affirmed that monetary accessibility along with monetary knowledge have a positive correlation to business survival, sustainability and viability of SMEs.

Table 3. Pearson Correlation coefficient

\begin{tabular}{|c|l|c|c|}
\cline { 3 - 3 } \multicolumn{2}{c|}{} & 1 & 2 \\
\hline 1 & SMEs' sustainability & - & - \\
\hline 2 & Monetary literacy & $0.509^{*}$ & $0.413^{*}$ \\
\hline 3 & Monetary access & $0.564^{*}$ & 0.0 \\
\hline
\end{tabular}

* Depicts correlation is significant at the 0.01 level (2-tailed).

Source: authors' calculation (2021).

Regression analysis: A linear regression analysis was demonstrated to establish the influence between the independent variables (i.e. monetary access and monetary literacy) and the dependent variable (DV) (i.e. SMEs' sustainability). The table below showcases the summary of outputs from the regression analysis.

Table 4. Regression Analysis

\begin{tabular}{|c|c|c|c|c|c|c|c|c|}
\hline $\begin{array}{c}\text { Variables } \\
\text { in the equation }\end{array}$ & B & Beta & $\mathrm{T}$ & $\mathrm{p}$-value & $\mathrm{R}^{2}$ & $\mathrm{~F}$ & Df & $\mathrm{p}$-value \\
\hline Constant & 11.575 & & 9.129 & $<0.0005$ & \multirow{3}{*}{0.411} & \multirow{3}{*}{104.569} & \multirow{3}{*}{$2 ; 300$} & \multirow{3}{*}{$<0.0005$} \\
\hline $\begin{array}{l}\text { Monetary } \\
\text { literacy }\end{array}$ & 0.343 & 0.333 & 6.851 & $<0.0005$ & & & & \\
\hline $\begin{array}{l}\text { Monetary } \\
\text { access }\end{array}$ & 0.429 & 0.427 & 8.773 & $<0.0005$ & & & & \\
\hline
\end{tabular}

Predictor: (Constant), monetary access \& monetary literacy.

DV: SMEs' sustainability.

Source: authors' calculation (2021). 
The outcome of the regression analysis in the table above showcased an R square of .411. This implies that monetary access and monetary literacy explain the $41.1 \%$ variation in the SMEs' sustainability. The standardised beta value of monetary literacy is $\beta=0.333, \mathrm{p}<0.0005$, while monetary access has a standardised beta value of $\beta=0.427, p<0.0005$. Based on the standardised beta value of the two independent variables, monetary access contributes more to SMEs sustainability in South Africa. The outcome of this statistical analysis is not surprising as the finding of a previous study conducted by Quartey, Turkson, Abor and Iddrisu (2017) suggests that access to finance is a crucial factor for SMEs' sustainability. Consistent with this finding, a study conducted by Mazanai and Fatoki (2012) revealed that the barrier of SMEs' sustainability in South Africa is access to finance. The current study's results are in agreement with those of Abdullah and Othman (2019), who observed that monetary access along with the intellectual capital has a positive impact on SMEs' resilience. Moreover, monetary literacy contributes to the survival as well as sustainability of SMEs by ensuring that they can deal with unexpected economic shocks as well as rapidly evolving credit and monetary markets (Lusardi, 2019). The results are also in conformity with Kumar and Bansal (2021), who discovered that monetary literacy allowed SMEs to recognise and reinvest in profitable market opportunities. Furthermore, monetary literacy promotes managerial accounting activities and reduces monetary errors, assisting SMEs in being more sustainable (Lusardi, 2019). However, the results of this study contradict those of Eresia-Eke and Raath (2013), who identified no connection between monetary literacy as well as SMEs' efficiency. Also, a study by Sauh, Abdullah and Rahman (2021) indicated a differing perception in the Pahang (a federal state of Malaysia) developed economy, as monetary access was found to be an insignificant factor of hindrance to business sustainability.

The findings support Abbas, Faridi and Rahman's (2020) conclusion that monetary access has a beneficial effect on SMEs' results. However, according to Ahlstrom, Cumming and Vismara (2018), SMEs have a harder time obtaining financing than big corporations. Due to the difficulty in obtaining financing, SMEs can resort to incompatible monetary resources, reducing their long-term sustainability. Furthermore, SMEs' monetary access has an impact on their development and creativity (Ye, Kulathunga, 2019). Overall, research shows that SMEs with greater access to resources are well positioned to maintain their profitability and survive in a modern dynamic market climate. SME access to appropriate competitive monetary services in developing markets is challenging (Effendi, Sunani, 2020). As a result, it is clear that SMEs in developing markets have limited access to capital, which leads to their low efficiency and overall failure rate. As a result, the results are in line with those of Yakubu, Sulemana and 
Abdallah (2020) and Khan, Li, Safdar and Khan (2019), who found that access to financing was a significant obstacle to SMEs' long-term sustainability. The value of the F-test in the regression analysis is an indication of the reliability of the regression model for making predictions.

\section{Concluding Remarks}

This paper examined the effect of monetary access and literacy on the survival and sustainability of SMEs. There are two key reasons why monetary literacy is so essential for SMEs' sustainability. First, regardless of access to finance, monetary literacy has a strong impact on the long-term sustainability of SMEs. Second, monetary literacy has a direct impact on monetary access, which in turn has an implicit impact on sustainability.

The pecking order theory used in this study suggested that operations and performance of a business is vested in higher management in the hierarchy. Similar outcomes supporting this theory are observed in the findings presented above. The essence of operating in the small business sector has meant that the survival of SMEs was dependent on the owner of the business and less on the employees. This is also related to decision-making, particularly monetary decisions such as investing. As much as the pecking order theory is observed, however, critical in assessing monetary literacy and monetary access is the human capital theory suggests that human intelligence is the driving factor to SMEs success and sustainability. One of the findings of this research is that monetary literacy is an outstanding factor affecting SMEs' sustainability. This is relatively modified by the human capital theory. Development in any economic sector is highly reliant on the information or knowledge acquired or possessed, hence human intelligence is the central measure of development. Similarly, the theory outline is relative to the outcome derived by this study.

From this paper the researchers recommend that workshops and regular training to help SMEs boost their monetary literacy should be coordinated and included in their yearly training and growth plan. Since these subjects are important to an organisation's monetary planning, the services can include bookkeeping, analysis of monetary statements, cash flow analysis, market environment assessment, risk evaluation, budget management and the advancement of project proposals. Specialized training such as finance for non-finance workers must be provided to every employee with a rudimentary understanding of monetary management. The establishment of a healthy SME sector in developing economies needs the greater participation of third parties such as policymakers. As a result, certain parties should arrange training especially for SMEs to improve their monetary literacy. These services should cover more than just accounting and 
recordkeeping, they should also cover monetary literacy and monetary management. Policies to increase SMEs' access to funding can also be introduced. SME development personnel, for example, may be assigned in each zone and tasked with improving the SME sector in their jurisdiction.

Monetary access was also described as a critical factor in SMEs' long-term viability particularly during and post COVID-19. Ensuring appropriate records could help SMEs gain better access to capital. This would make it possible for them to obtain structured financing and avoid relying on costly, unverified sources. As a result, the researchers recommend that SMEs adopt advanced accounting processes and cultivate close partnerships with commercial banks. Such connections will help SMEs keep up with new monetary assistance services offered by various organizations. As a result, SMEs can solve the issue of the equity divide by using the most suitable source of capital. To support the growth and sustainability of SMEs, government and banks are sole support centers that must be easily accessible. Bearing in mind the lack of monetary and commercial support knowledge the support segments to these sectors must be segmented across communities for simple and easy access. The banking system to support SMEs needs to be simple and friendly like opening a bank account to ensure as many SMEs reach out for support rather than collapsing. Most, if not all, qualifications in the tertiary education sector and high school should integrate a few monetary subjects that will equip and capacitate students with monetary skills. This subject package should also include entrepreneurship as this would assist a number of aspiring entrepreneurs through providing knowledge of basic business skills needed in the business environment. SMEs should also look for alternate sources of capital, according to the study. It is critical for SMEs to take more initiative and become less reliant on traditional sources of funding, such as bank loans. Crowd fundraising may be used as a supplementary funding mechanism. Crowd funding is a new and crucial kind of financing in which a group of individuals contribute to a contingency fund by making tiny contributions in the form of stock purchases.

In light of the interruption caused by COVID-19, all parties participating in the growth of SMEs, namely public and private entities, should help SMEs enhance their monetary literacy skills. Long and short monetary literacy strategies might be created from these plans. Firstly, A short-term strategy may include establishing an urgent business fund, developing a spending plan to prioritize and analyze monetary resources, deferring any business growth at this time, and focusing on what the company can manage in the short term. Secondly, the long term plan may include reconsidering a long-term spending plan to maintain their enterprises under the new circumstances imposed by the pandemic, proactively participating in public and private 
financial assistance programs, leveraging online technology to increase business revenues as well as marketing, taking benefits of reduced operating expenses, and ramping up philanthropic involvement.

The findings presented in this section and the outline of the paper will also be instrumental to scholars as they may draw differing conclusions to the outcomes presented and also use this study as their guide to future research. The limitation of this paper was that the demographic information was not correlated with the responses from the various categories, namely the retail, construction, agriculture and manufacturing sectors. Such a correlation is recommended for future work.

\section{References}

Abbas, M., Faridi, M.Z., Rahman, S. (2020). Assessing the factors affecting growth of small firms in Pakistan. European Journal of Applied Business and Management, 6 (1), 77-89.

Abdullah, N.N., Othman, M.B. (2019). Examining the effects of intellectual capital on the performance of Malaysian food and beverage small and medium-sized enterprises. Technology (IJCIET), 10 (2), 135-143.

Adetiba, T.C., Qwabe, N.T. (2020). The wave of unemployment amongst South African youths: belonging to a political organisation as a way of escape? e-Bangi, 17 (5).

Ahlstrom, D., Cumming, D.J., Vismara, S. (2018). New methods of entrepreneurial firm financing: Fintech, crowdfunding and corporate governance implications. DOI: https://doi. org/10.1111/corg. 12258 .

Amin, S. (2018). Does the entrepreneurial human capital is important for organizational performance? Business and Economics Journal, 9 (2), 1-5.

Balogun, O.A., Agumba, N.J., Ansary, N. (2018). Determinants of business overdraft accessibility within small and medium-sized enterprises in the South African construction industry: A case of Gauteng province. In: Proceedings of the 21st International Symposium on Advancement of Construction Management and Real Estate (pp. 617-628). Singapore: Springer.

Bartolacci, F., Caputo, A., Soverchia, M. (2020). Sustainability and monetary performance of small and medium sized enterprises: A bibliometric and systematic literature review. Business Strategy and the Environment, 29 (3), 1297-1309. 
Barua, R., Koh, B., Mitchell, O.S. (2018). Does monetary education enhance monetary preparedness? Evidence from a natural experiment in Singapore. Journal of Pension Economics \& Finance, 17 (3), 254-277.

Becker, G.S. (1962) Investment in human capital: A theoretical analysis. Journal of Political Economy, 70 (5), 9-49.

Bongomin, G.O.C., Munene, J.C., Ntayi, J.M., Malinga, C.A. (2018). Exploring the mediating role of social capital in the relationship between monetary intermediation and monetary inclusion in rural Uganda. International Journal of Social Economics, 45 (5), 829-847.

Bushe, B. (2019). The causes and impact of business failure among small to micro and medium enterprises in South Africa. Africa's Public Service Delivery and Performance Review, 7 (1), 1-26.

Camfield, C.E.R., da Silva Freitas, G.M., Correia, M.R.F., Serrasqueiro, Z. (2018). The capital structure of small companies in Portugal: an approach according to trade-off and pecking-order theories. Race: magazine of administration, accounting and economics, 17 (1), 365-388.

Changwesha, M. (2019). The relationship between monetary literacy and monetary access among SMEs in the Ekurhuleni Metropolitan Municipality, South Africa (Doctoral dissertation).

Chaudhuri, K., Sasidharan, S., Raj, R.S.N. (2020). Gender, small firm ownership, and credit access: Some insights from India. Small Business Economics, 54 (4), 1165-1181.

Derbyshire, E., Fouché, J. (2018). Analysing the Needs of Small and Micro-Enterprise Owners: A South African Suburb Case Study. International Journal of Business and Management Studies, 10 (2).

Effendi, M.B., Sunani, A. (2020). Analysis of Access to Monetary Services on Poverty Alleviation with MARS Approach. Journal of Economics, Business, \& Accountancy Ventura, 23 (1), 125-137.

Fatoki, O. (2018). The impact of entrepreneurial resilience on the success of small and medium enterprises in South Africa. Sustainability, 10 (7), 2527.

Fix, B. (2018). The trouble with human capital theory. Real-world economics review, 86 (1), $15-30$.

Garg, N., Singh, S. (2018). Monetary literacy among youth. International Journal of Social Economics, 45 (1), 173-186.

Grohmann, A. (2018). Monetary literacy and monetary behavior: Evidence from the emerging Asian middle class. Pacific-Basin Finance Journal, 48, 129-143.

Grohmann, A., Klühs, T., Menkhoff, L. (2018). Does monetary literacy improve monetary inclusion? Cross country evidence. World Development, 111, 84-96. 
Gyimah, P., Appiah, K.O., Lussier, R.N. (2020). Success versus failure prediction model for small businesses in Ghana. Journal of African Business, 21 (2), 215-234.

Hoaglin, D.C. (2016). Misunderstandings about Q and 'Cochran's Q test' in meta-analysis. Statistics in medicine, 35 (4), 485-495.

Kamanga, T. (2018). The role of monetary literacy in monetary inclusion in emerging markets: evidence from South Africa (Master's thesis, University of Cape Town).

Khan, N.U., Li, S., Safdar, M.N., Khan, Z.U. (2019). The role of entrepreneurial strategy, network ties, human and monetary capital in new venture performance. Journal of Risk and Monetary Management, 12 (1), 41.

Kitomo, D., Likwachala, R., Swai, C. (2021). Monetary Management Practices Among Micro Enterprises and their Implications for Loan Repayment: A Case of Solidarity Group Lending of DCB Commercial Bank in Dar es Salaam. International Journal of Economics and Finance, 12 (12), 122-122.

Kulathunga, K.M.M.C.B., Ye, J., Sharma, S., Weerathunga, P.R. (2020). How Does Technological and Monetary Literacy Influence SME Performance: Mediating Role of ERM Practices. Information, 11 (6), 297.

Kumar, J., Bansal, G. (2021). Impact of monetary literacy (FL) and access to banking services (AC) on monetary well-being (FWB): an empirical study. Jitender Kumar and Garima Bansal, Impact of Monetary Literacy (FL) and Access to Banking Services (AC) on Monetary Well-being (FWB): An Empirical Study, International Journal of Management, 11 (12), 2020.

Lajuni, N., Bujang, I., Karia, A.A., Yacob, Y. (2018). Religiosity, monetary knowledge, and monetary behavior influence on personal monetary distress among millennial generation. Jurnal Manajemen dan Kewirausahaan, 20 (2), 92-98.

Leboea, S.T. (2017). The factors influencing SME failure in South Africa (Master's thesis, University of Cape Town).

Lusardi, A. (2019). Monetary literacy and the need for monetary education: evidence and implications. Swiss Journal of Economics and Statistics, 155 (1), 1-8.

Lyons, A., Kass-Hanna, J., Liu, F., Greenlee, A., Zeng, L. (2020). Building monetary resilience through monetary and digital literacy in South Asia and Sub-Saharan Africa. Available at SSRN 3496562.

Manzoor, F., Wei, L., Sahito, N. (2021). The role of SMEs in rural development: Access of SMEs to finance as a mediator. Plos one, 16 (3), e0247598.

Marecha, T. (2020). Business planning and entrepreneurial education: key drivers for SME performance in South Africa's Gauteng Province (Doctoral dissertation). 
Matias, F., Serrasqueiro, Z. (2017). Are there reliable determinant factors of capital structure decisions? Empirical study of SMEs in different regions of Portugal. Research in International Business and Finance, 40, 19-33.

Maziriri, E.T., Chivandi, A. (2020). Modelling key predictors that stimulate the entrepreneurial performance of small and medium-sized enterprises (SMEs) and poverty reduction: Perspectives from SME managers in an emerging economy. Acta Commercii, 20 (1), 1-15.

Méndez-Morales, A. (2019). Show me the money: Pecking order and funding sources for innovative firms in Colombia/Dejamever el dinero: ordenjerarquico y fuentes de par aempiesasinnovadorasen Colombia/Deixe-me ver o dinheiro: ordemhierarquica e fontes de financiamento para empresasinovadorasna Colombia. Revista Cuadernos de Administración, 32 (59), NA-NA.

Mincer, J. (1958). Progress in human capital analysis of the distribution of earnings. National Bureau of Economic Research. Cambridge, MA.

Muo, I., Oladimeji, M.S., Okunbadejo, O.I. (2020). Monetary Bootstrapping and Small Business Growth in Lagos Metropolis, Nigeria. Izvestiya, 2, 198-213.

Ndiaye, N., Razak, L.A., Nagayev, R., Ng, A. (2018). Demystifying small and medium enterprises'(SMEs) performance in emerging and developing economies. Borsa Istanbul Review, 18 (4), 269-281.

Owusu, J., Ismail, M.B., Osman, M.H.B.M., Kuan, G. (2019). Monetary literacy as a moderator linking monetary resource availability and SME growth in Ghana. Innovations, 16 (1), $154-166$.

Quartey, P., Turkson, E., Abor, J.Y., Iddrisu, A.M. (2017). Financing the growth of SMEs in Africa: What are the contraints to SME financing within ECOWAS? Review of development finance, 7 (1), 18-28.

Rambe, P., Mosweunyane, L. (2017). A poverty-reduction oriented perspective to small business development in South Africa: A human capabilities approach. African Journal of Science, Technology, Innovation and Development, 9 (3), 289-302.

Sabri, M.F., Aw, E.C.X. (2019). Monetary literacy and related outcomes: the role of monetary information sources. International journal of business and society, 20 (1), 286-298.

Schultz, T.W. (1961). Investment in human capital. The American Economic Review, 51 (1), 1-17.

Msomi, T., Olarewaju, O. (2021). Evaluation of access to finance, market and viability of small and medium-sized enterprises in South Africa. Problems and Perspectives in Management, 19 (1), 281-289. DOI: 10.21511/ppm.19(1).2021.24.

Udell, G.F. (2020). SME Access to Finance and the Global Monetary Crisis. Journal of Monetary Management, Markets and Institutions, 8 (01), 2040003. 
Usama, K.M., Yusoff, W.F.W. (2018). The relationship between entrepreneurs' monetary literacy and business performance among entrepreneurs of Bauchi State Nigeria. International Journal of Entrepreneurship and Business Innovation, 1 (1), 15-26.

Van Deventer, M., De Klerk, N. (2017). Monetary Literacy Amongst African Generation Y Students: An Empirical Analysis of Selected Demographic Factors. International Journal of Economics and Finance Studies, 9 (1), 235-251.

Yakubu, I.N., Sulemana, A.M., Abdallah, I. (2020). Small and Medium-Sized Enterprises Financing. Grading Journal for Social Sciences, 23 (2), 1-8.

Ye, J., Kulathunga, K.M.M.C.B. (2019). How does monetary literacy promote sustainability in SMEs? A developing country perspective. Sustainability, 11 (10), 2990.

Zerihun, M.F., Makgoo, D.M. (2019). Assessment of Monetary Literacy on Monetary Management Outcomes: Evidence from the South Africa Employed Youth. Journal of Global Business \& Technology, 15 (2).

\section{Citation}

Msomi, T.S., Olarewaju, O.M., Ngcobo, X. (2021). Sustaining South African small and medium-sized enterprises through monetary access and literacy in the COVID-19 era. Folia Oeconomica Stetinensia, 21 (2), 57-75. DOI: 10.2478/foli-2021-0016. 